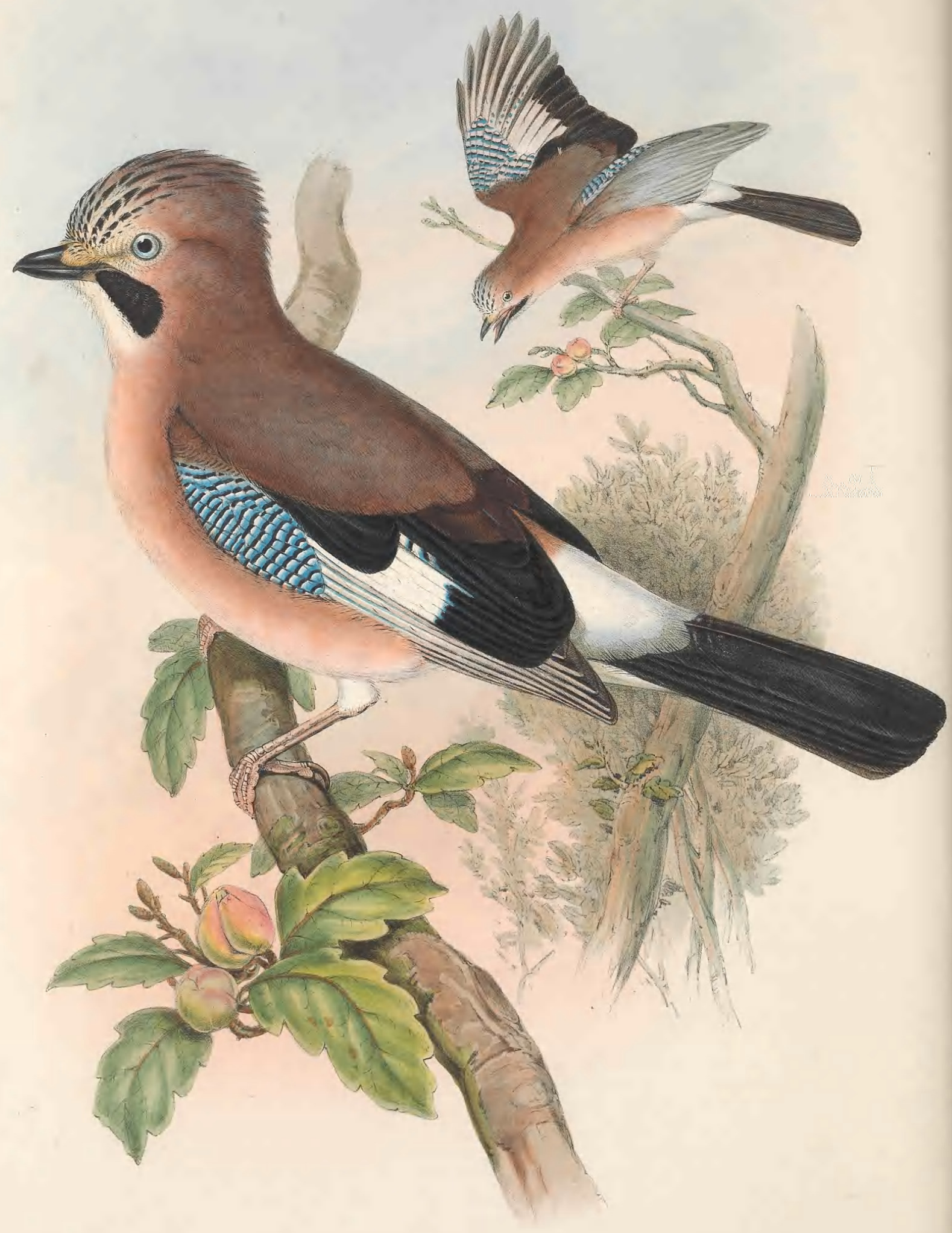

GARRULUS GLANDARIUS。 


\section{GARRULUS GLANDARIUS.}

Jay.

Corvus glandarius, Linn. Syst. Nat., tom. i. p. 256.

Pica glandaria, Klein, Av., p. 61.

Garrulus glandarius, Flem. Brit. Anim., p. 86.

Glandarius pictus, Koch, Syst. Baierisch. Zool., p. 99.

IF birds had the faculty of speech, the Jay might appropriately exclaim, " Save me from my friends, and I will endeavour to avoid my enemies; by the former I am often imprisoned for my grotesque actions and beautiful plumage, and the latter are always waging war with me for certain pilfering habits and other little misdeeds which it is my nature to commit." To myself, personally, it is rery pleasing that our avi-fauna comprises so charming a bird; and although I cannot but plead guilty to having often raised my gun at this woodland tenant, I hope to be more sparing in future. Impulsively, however, does every sportsman take his shot at the Jay, when it deridingly passes over his head in the midst of our great covers. Hundreds are thus killed during the pheasant-shooting season, and it requires all the craftiness with which the bird is endowed to keep it out of harm's way. Of course it finds still less favour with the keeper and the gardener, eggs and cherries having irresistible charms for its palate.

In the days of Linnæus, the Crow, the Jay, and the Magpie were all associated under the generic title of Corvus; but the three birds have since with great propriety been made the types of as many genera, the old name of Corvus being retained for the true Crows, while that of Pica is assigned to the Magpies, and Garrulus to the Jays. That such a separation is both natural and proper no ornithologist of the present day will attempt to deny. Structurally each differs from the other, while at the same time the plumage of all the known members of the three forms is strictly in unison, and never partakes of the colouring of either of the others. Of course their habits and economy are modified in accordance with their difference of form. Their distribution teaches us some interesting facts. The members of the genus Corvus are more widely spread than those of the genus Pica, and the latter more so than those of the genus Garrulus; still the last-mentioned form has representative species in nearly every part of the northern portion of the Old World; that is, Jays are found from the island of Japan in the east to Ireland in the west, while in North Africa there is one species not found elsewhere.

In the Americas, both North and South, many representatives of this family occur, but these have been assigned by modern systematists to distinct genera. The following is a tolerably correct list of the species of the true Jays, genus Garrulus. In the Japanese islands there are two, G.japonicus and G. Brandtii; in China one, very similar to, but distinct from, the $G$. bispecularis of the Himalaya. To this bird I many years since assigned the name of $G$. sinensis. In the Amoor and the Altai the $G$. Brandtii occurs, as well as in Japan. The fauna of India claims the G. bispecularis, G. lanceolatus, and G. Lydthii; Syria and Asia Minor, the G. melanocephalus; North Africa, the G. cervicalis and G. glandarius; and Europe, the G. glandarius and $G$. melunocephalus, the former being found throughout the whole of the continent, from Spain and the Grecian islands to Great Britain, Sweden, and Norway. Thus we find that, in lieu of the one known to the learned Swede, we are now acquainted with no less than eight species of this particular form.

With these prefatory remarks, we may proceed to a more detailed history of one of the most beautiful and ornamental of the British birds. First, then, I may state that the Jay is strictly stationary in Great Britain ; and that its numbers do not appear to be increased by accessions from other countries, nor have we any reason to believe that those which are bred here ever leave our islands. Mr. Rodd states that, in Cornwall, it is very rare in the neighbourhood and to the westward of Penzance, but that it is common in the woodland districts of that county. From this western point it is very generally distributed over the whole of England and Wales; it is also found, but in far less numbers, in the southern and midland counties of Scotland and Ireland, in which latter country, I trust, it is now in better favour than in the days of George the Second, when a price was put upon its head, from an unfounded imputation that it did injury to young trees.

Unlike the Crow, whose structure is alike adapted for aërial, arboreal, and terrestrial progression, the wingpowers of the Jay are somewhat restricted, as are also its powers of progression over the surface of the earth; but whatever is denied to it in this respect is amply compensated by a structure admirably befitting its arboreal habits. If we examine the form of its foot, we find its hind toe and claw largely developed, and placed on the same plane as the anterior ones. This hand-like foot is admirably adapted for grasping the smaller branches of trees, and hence it is that the bird is always found in thick woods and hedgerows. In winter it is often solitary, living in the midst of the most extensive covers, where perchance the only other 
bird-life that exists is the Pheasant and the familiar little Robin. In these secluded retreats it noiselessly searches for fallen acorns, wild nuts, and such insect-food as its prying eye may detect. In the spring-time it becomes more noisy and animated, frequents the outer glades and pathways, builds on some low tree often within reach of the hand, and, if the nest be not detected by the keeper or juvenile birds-nester, it rears its four or five young ones, which, as soon as they are fledged, follow in the train of their parents for the remainder of the autumn. Sometimes two or three broods unite and form a small community, which appear to live in harmony. In their usual habits they are still and quiet; but a poaching cat, snared hare, prowling fox, or anything strange is sure to attract their attention; their energies are then aroused, they become all animation, and their garrulous and harsh cry is oft repeated. This trait in the character of the Jay is at least useful to the keeper of game, as it directs him at once to the spot where danger to the objects of his care may be apprehended. In its thievish habit of stealing eggs the Jay displays great energy and diligence, descending to the lowest branches of the trees and surveying everything with the most prying and inquisitive eye. Strictly omnirorous, it also feeds on chafers and other large Coleopterous insects, worms, mice, frogs, young birds, \&c. : this kind of food is varied with the fruits of the wild-cherry berries, or any of the products of the garden. Besides uttering its own harsh, disagreeable note, it has a power of mimicry, excelling, perhaps, that of any other bird; every sound, from the crowing of a cock to the mewing of a cat, being within the range of its imitative powers.

Notwithstanding the rather bad character I have given to the Jay, I am sure that, from the nobleman down to the humblest lover of nature, we should all be sorry not to have the bird amongst us. Let a necessary check only be exercised to keep its numbers within bounds, and the "larder" of the keeper be more sparingly graced than it usually is; and let us see less of the revolting sight so frequently exhibited, of numbers of this bird impaled, with many others so wrongfully called vermin. What would our existence be without bird-life in all its varied forms? It may be truly said to be one of the most pleasing of Nature's works. The colours of the Jay, when seen during flight, are very attractive; for the white of its upper tailcoverts and its wing-markings are then displayed to great advantage, and their hues form a striking contrast to the colours of the other parts of the plumage. On a nearer acquaintance, the delicacy of its tints and the beauty of its wings are very charming ; and surely it is not the province of any of our great landed proprietors utterly to destroy this handsome bird.

The nest is of a cup-shaped form, about 9 inches in diameter, and is constructed of crooked sticks and coarse roots, neatly lined with other extremely fine hair-like roots and a few hairs. The eggs are five or six in number, and of a yellowish white, thickly speckled all over with light brown; they are 1 inch and 4 lines in length, by 1 inch in breadth.

Like other Corvine birds, little or no difference is observable in the colouring of the sexes; neither are the young differently clothed - a nest of young Jays, by the time they are ready to fly, exhibiting all the colours with which their parents are adorned.

Forehead and space around the eye greyish white, with a streak of black down the centre of each feather, the tips of those approaching the occiput becoming of the same cinnamon-brown hue as the back and sides of the neck, back, and lesser wing-coverts; from each side of the lower mandible a broad streak of black, forming a conspicuous moustache; chin dull white; breast and abdomen grey, washed with vinous brown, which becomes the prevailing hue on the flanks; lower part of the abdomen, vent, thighs, upper and under tail-coverts white; greater wing-coverts barred on their external webs and at the tip of the inner web with black, deep and pale blue alternately, the base of the inner web brown; primaries black, all but the first margined with dull white; secondaries black, the basal half of the external web snow-white; tertiaries barred across the base of the outer web with blue, the two or three nearest the body chestnut, tipped with black; tail dull black, indistinctly barred with blue at the base, the outer feather paler than the others above, and greyish beneath; legs, feet, and claws flesh-colour; bill black, becoming of a fleshy hue at the base of the under mandible; irides pale-bluish white.

The Plate represents an adult male of the natural size, and a female in the distance. 


\section{$2 \mathrm{BHL}$ Biodiversity Heritage Library}

Gould, John. 1873. "Jay, Garrulus glandarius [PI. 64]." The birds of Great Britain 3, -. https://doi.org/10.5962/p.323952.

View This Item Online: https://www.biodiversitylibrary.org/item/221726

DOI: https://doi.org/10.5962/p.323952

Permalink: https://www.biodiversitylibrary.org/partpdf/323952

\section{Holding Institution}

Smithsonian Libraries

\section{Sponsored by}

Biodiversity Heritage Library

\section{Copyright \& Reuse}

Copyright Status: Public domain. The BHL considers that this work is no longer under copyright protection.

This document was created from content at the Biodiversity Heritage Library, the world's largest open access digital library for biodiversity literature and archives. Visit BHL at https://www.biodiversitylibrary.org. 